

\section{Art, science and religion in Romeyn de Hooghe's Hieroglyphica}

Joke Spaans

Romeyn de Hooghe (I645-I708) is best known as the prolific producer of high-quality loose-leaf prints, book illustrations and frontispieces. He left an astounding volume of etchings and engravings, in a wide variety of genres, but all bearing his distinctive style. Near the end of his life, however, he also wrote two substantial books that so far have hardly attracted scholarly attention. The first one, his Spiegel van Staat des Vereenigde Nederlands, has recently been noted for its contribution to the history of republicanism. ${ }^{.}$His Hieroglyphica of merkbeelden der oude volkeren, namentlyk Egyptenaren, Chaldeeuwen, Feniciers, Joden, Grieken, Romeynen, enz. Nevens een omstandig Bericht van het Verval en voortkruypende Verbastering der Godsdiensten door verscheyde eeuwen; en eyndelyk de Hervorming, tot op deze tyden toe vervolgt, ${ }^{2}$ published posthumously, reflects De Hooghe's mature views on religion. Among its more than 400 pages of text, De Hooghe placed 63 full-page etchings. Rather than being simply illustrations accompanying the text of his book, the etchings present his argument, whereas the text 'illustrates' - in its literal meaning, 'sheds light on' - the plates. Each plate and chapter is dedicated to a specific theme in the genealogy of the Christian religion.

As the title promises, De Hooghe uses many of the conventions of a genre that enjoyed some popularity during his time. Owing to the inspiration of the impenetrable Egyptian hieroglyphs, the sixteenth and seventeenth centuries saw the production of several books in which images and objects were treated as references to multiple layers of meaning. Besides the obvious 'literal' connection between an image and the concrete object it depicted, 'hieroglyphical' authors identified each and every possible meaning of an image (or word), with a predilection for metaphorical and moral connotations and hidden clues to ancient, occult wisdom. ${ }^{3}$ In Chapter 2, De Hooghe claims to have expanded and modernised this genre in his Hieroglyphica. He argues that from antiquity, the production of hieroglyphs has always continued. And, as many of the symbols of the ancients have been lost - and, moreover, in many subjects modern scientists have superior knowledge - modern symbols, like those devised for use in navigation, distillation techniques or telescopy, are of even more use to his European readers than those derived from antiquity. ${ }^{4}$ Scattered through the Hieroglyphica we find many references to the natural sciences. Usually they support De Hooghe's critique of the forms
Detail fig. 9

De Hooghe, Toepassing, 1690-1708 (detail: left margin). 
of organised religion he saw in his own time and his proposals for further reformation, which are the mainstay of the book as a whole.

\section{De Hooghe and the scientific knowledge of his time}

Romeyn de Hooghe's claims to scholarship are shaky at best. In his youth he reputedly visited the Latin school run by Franciscus van den Enden (I602-I674), where the young Baruch de Spinoza (I632-I677) also went.5 Later in life he gained - or, as rumour had it, bought - a doctorate in law at the University of Harderwijk. ${ }^{6}$ His real education, however, came from a wide network of contacts among the intellectual elite and access to their conversations, libraries and collections. Despite his lack of formal education, it can be said that, in a very real sense, the prints in Hieroglyphica were the result of a lifetime of study.

In the Hieroglyphica, De Hooghe tells an anecdote, which perfectly illustrates how he, as an ambitious artist, participated in a network of regents and scholars. Considerable difference in social rank and level of education did not preclude forms of conviviality providing someone like De Hooghe with the latest news on discoveries in the natural sciences and on the debates they provoked in the field of theology. Fun was to be had here too, as in the cartoon that was the conversation piece at the occasion described by De Hooghe:

Once, at the home of the late Lord Exchequer Burgh, I saw Atlas and Hercules struggling to keep the earth in its orbit, now that Copernicus had upset the system of the cosmos. Tycho Brahe had his shoulders set under the globe, and Ptolemy came to his help, screaming in distress, to prevent the world from shattering in its fall. Meanwhile Copernicus kicked in the crystal spheres surrounding the earth and under his foot extinguished their twinkling lights. Gassendi came running and with huge effort pushed the sphere from its mountain top, so that, once fallen from the shoulders of Atlas, the world attained uniform motion. The design was by the Lord of Zelhem and the Oxford Society. It also contained several wellknown stargazers and moonrummagers of our times coming to blows over the question whether the earth is stationary or moving. ${ }^{7}$

Here we find De Hooghe at the house of a prominent Dutch regent. The 'late Lord Exchequer Burgh' is Coenraad van den Burgh (I623-I669). He was a very wealthy man, son of an Amsterdam burgomaster, himself an alderman of that great city. As befitted a man of his stature he lived in a large house on the Heerengracht. He also possessed a manor and was entitled to call himself Lord of Kortenhoef. Since 1666 he was head of the Treasury of the States General. His wife was Cornelia Hooft, a daughter of the famous poet Pieter Cornelis Hooft (I58I-I647), who was also a high government official in the Gooi area, east of Amsterdam. ${ }^{8}$ The artist and the regent had enjoyed a satirical drawing or print on the lively debates on heliocentrism in the second half of the seventeenth century.

Perhaps the designer of the image, Christiaan Huygens (I629-I695), 
Lord of Zelhem, had also been present. Huygens was the scion of a family that had been in the service of the Stadholders for three generations, and a renowned scientist. He may have brought the piece of artwork that engaged the company at the house of Van den Burgh with him.

Christiaan Huygens had a life-long passion for astronomy. He designed and used telescopes to observe the moon, the planets and the stars. He was the first to describe the rings of Saturn, and he discovered one of its moons, Titan. In his views of the world system, he held with the heliocentrism of Nicolaus Copernicus (I473-I543), and he worked to strengthen the arguments in favour of this theory, which during his time was not yet universally accepted. ${ }^{9}$ He calculated the orbits, distances and sizes of the planets. He published several tracts on cosmology and corresponded on the subject with other scholars through the Royal Society in London and the Académie royale in Paris.

Aside from his serious work, Huygens also appears to have produced satire. The above-mentioned print or drawing - unknown so far, and probably lost - ridicules Ptolemy, the architect of the geocentric cosmos and its defender Tycho Brahe (I546-I60I). The latter had devised an improved system of a geocentric cosmos, one that predicted the positions of the heavenly bodies as well as the Copernican system did. At the same time it salvaged the authority of Aristotelian philosophy and the Bible. Reformed theologians objected to Copernicanism because of its contradiction of these traditional authorities. The most adamant of them was Gisbertus Voetius (I589-I676), professor of theology and rector magnificus at Utrecht University. Voetius was no astronomer. His position in this debate was determined by his rejection of the philosophy of René Descartes (I596-1650). The latter's hermeneutics of systematic doubt struck many theologians as godless. Descartes's cosmology, in which he followed Copernicus, was just one of the dangerous innovations that, in the eyes of Voetius, threatened theology and religion. ${ }^{10}$ Huygens despised these theological objections. Among the skirmishing defenders and opponents of geocentrism in the above-mentioned cartoon, Voetius may well have been included.

Besides the elusive cartoon, Huygens's Cosmotheoros may have a satirical meaning as well. The treatise - originally written in Latin but quickly translated into all main European languages - is written in the form of two consecutive letters to Christiaan's brother Constantijn Jr. (I628-I697). It is obviously firmly based on Huygens's own observations and computations. It describes the system of the world as it would appear not only to Earth-based observers, but also to the presumed inhabitants of the other planets. It does so with an impressive array of calculations and estimations of orbits and relative planetary masses. ${ }^{\text {II }}$ The largest part of the first letter, however, is taken up with elaborate speculations about inhabitants of other worlds, the so-called Planetarians. Huygens argues that, as other planets have geological and meteorological characteristics mountains, seas, and clouds - similar to those of Earth, it stands to reason that they also have life, and most probably sentient life. From there it naturally follows that these hypothetical Planetarians also have economies and cultures, providing them with everything from food and shelter to 
music, and even pocket watches like those Huygens himself had invented. Imperceptibly, Huygens's argument segues from bona fide scientific theory into literary pastiche. This part reads like a satire on the absurdities resulting from attempts to describe the natural world without proper recourse to observation and experiment. It seems directed at the antiCopernican theologians. Their rejection of a plurality of worlds was based on theological claims that Man is the centre and final cause of Creation, and that it is sinful to inquire beyond that which God has revealed in Scripture.

The seventeenth century saw a small crop of literary fantasies about extraterrestrial life. All are utopian satires. ${ }^{12}$ Like no other scholarly pursuits at that time, astronomy and cosmology demonstrated the need for a new natural philosophy - and for serious reflection on the underpinnings of theology and religion. We find this awareness explicitly formulated by the Amsterdam minister Balthasar Bekker (I634-I698) in his controversial book De betoverde weereld. He deplored the relative neglect of mathematics and astronomy - studies that did not give access to lucrative jobs, as did the traditional studies of law, medicine or theology - because nowhere was it more obvious that the orthodox worldview depended on 'prejudice', that is, upon blindly following traditional authority instead of open-minded rational inquiry. ${ }^{13}$ Bekker's alternative readings of Biblical texts on devils, angels and demons, rejecting - and occasionally ridiculing - traditional authorities, came up against the same theological objections that also riddled the reception of Copernicanism. ${ }^{I 4}$ In Cosmotheoros, Huygens likewise pokes fun at the unwillingness or inability of scholars to acknowledge the insufficiency of current theories to explain the more baffling observations of nature and to think outside their conceptual boxes. ${ }^{\text {Is }}$ It is probably no simple oversight that Huygens does not credit his watch-toting Planetarians with having a religion. ${ }^{16}$

Participation in the seventeenth-century debates on the compatibility of science and religion, and more generally on Cartesian philosophy, was not restricted to the learned world of the academy. Often the more original contributions were ventilated in socially mixed networks of intellectuals, meeting in bookshops and coffee houses, sharing their insights in correspondence networks, private libraries and cabinets of curiosities. Here we find leisured regents, technical professionals like engineers and navigators, and a growing class of men of letters who served as diplomats, agents, spies and newsagents. The meeting between Van den Burgh and De Hooghe is a good example. Some of these cultured amateurs rejected much of traditional scholarship and Christian doctrine in favour of a more rationalist worldview and/or new political philosophies. When they published their views, they usually did so in the vernacular, instead of academic Latin. ${ }^{17}$ In these proposals for radical reform, ministers were often painted in the blackest of colours, as demagogues and rabble-rousers, who undermined the authority of the state and ridiculed modern scholarship before the ignorant masses. ${ }^{18}$

Attacks upon the established authorities in philosophy and theology were not without risk, however. From the middle of the seventeenth 
century the States of Holland repeatedly issued resolutions that prohibited any philosophical activity that might undermine the doctrine of the Reformed Church. Hefty fines and prison sentences discouraged straightforward publication of the more radical ideas. ${ }^{19}$ Censorship, however, could be evaded. A literary underground of radical philosophical texts developed in the latter decades of the century. ${ }^{20}$ Literature and the graphic arts offered an alternative way to represent controversial ideas covertly - that is, in such a way that they would be noticed only by a discriminating intellectual audience. The established poets kept aloof, but the satire of Cosmotheoros is an example of such a literary disguise. References to the new cosmology could also be shown in the ornamental borders of expensive decorative wall-maps and the plates of atlases. ${ }^{21}$

Perhaps the most spectacular example of a radical-philosophical argument presented in the pictorial language of allegorical print is Romeyn de Hooghe's Hieroglyphica. In this work, De Hooghe develops a critique of early modern religion, based, among other things, on the new cosmology. Here De Hooghe proves that he was confidently at home in the post-Cartesian intellectual climate (fig. I), where new discoveries in the natural sciences and reports about exotic cultures were evaluated in the light of the ongoing study of antiquity and the Bible, transforming the traditional understanding of the world based on Aristotelian principles. He was, moreover, very well informed on current political and theological discussions. Religion had itself become a focal point in early Enlightenment thought, and De Hooghe's Hieroglyphica offers one of the more radical contributions to this field. ${ }^{22}$ Placed within the context of De Hooghe's 'religious' oeuvre, it becomes an eloquent blueprint for an enlightened spirituality.

\section{From Catholic devotion to enlightened critique of religion}

De Hooghe does not have a reputation for religiosity: quite the contrary. In the early I690 he was the target of an incredibly vile smear campaign, originating with anti-Orangist Amsterdam regents. As an avowed partisan of William III (I650-I702), De Hooghe had refused a commission to lend them his pen and etching needle. They retaliated with a flurry of defamatory pamphlets, portraying De Hooghe as a kleptomaniac, a sexual pervert and an atheist. None of these accusations could be substantiated, but De Hooghe, who gave as good as he got in the exchange, was never officially rehabilitated. By that time he had left Amsterdam to settle in Haarlem, where he opened a drawing academy. There he lived as an honourable member of the urban elite and a minor regent. Not only did he receive several commissions from the magistracy, but also he was considered fit to serve as deacon in the Reformed Church and as judge in one of the lower courts of justice. Of course the juicier pieces of slander could never be unsaid, however, and have blackened his reputation ever since. ${ }^{23}$

Although clearly a libertine, De Hooghe was probably not the stark atheist later historiography has made him. Much of his work is concerned 


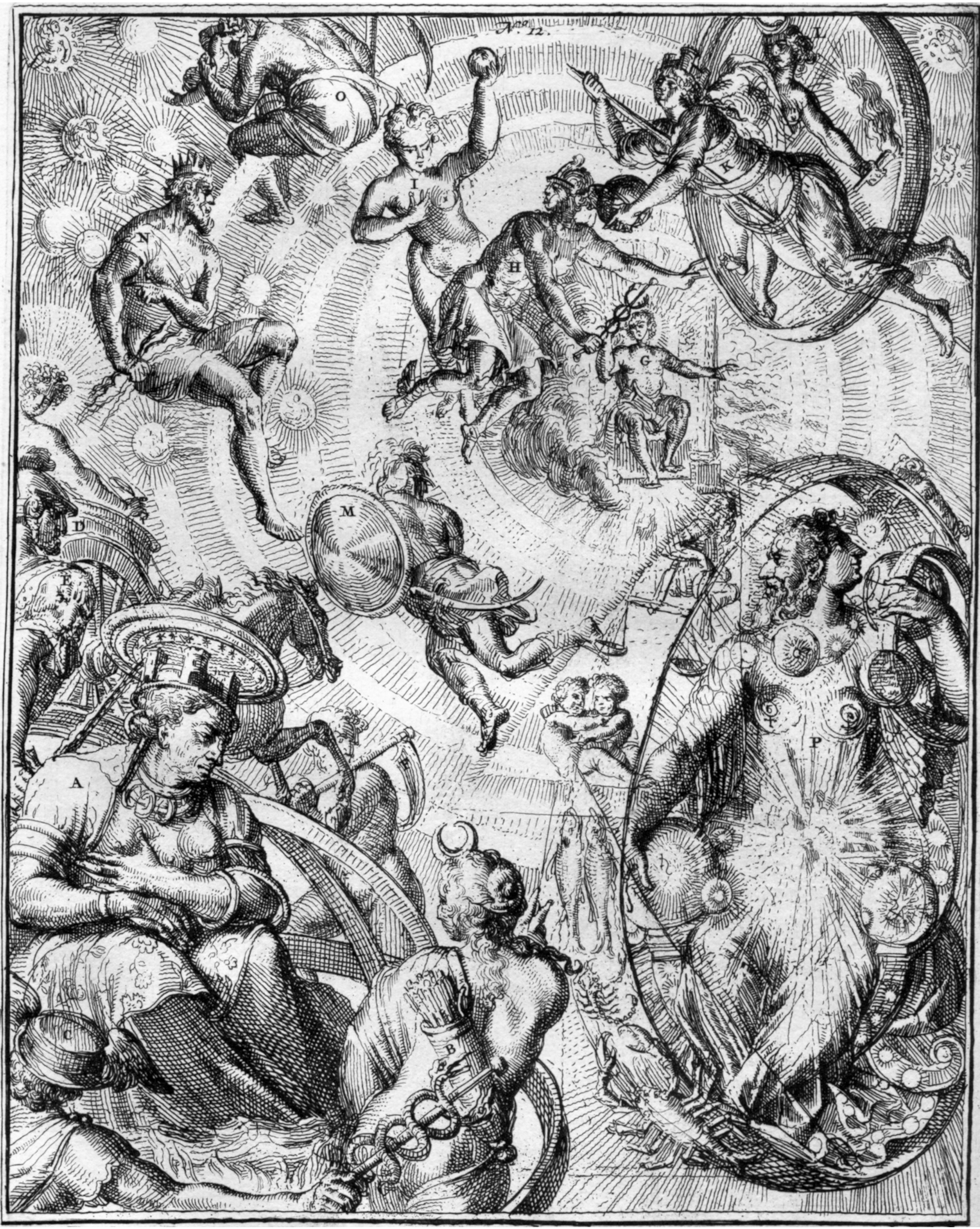


with religion. From the very beginning of his artistic career he acquired commissions for book illustrations, many of them for works of religious edification. In itself this is not surprising: a large proportion of early modern book production was made up of theology and devotion. ${ }^{24} \mathrm{He}$ illustrated religious works by authors of a wide variety of confessional backgrounds. He also contributed title pages and illustrations to Lutheran and Reformed Bibles. This ecumenicity was not unusual at the time. ${ }^{25}$ In the case of De Hooghe, however, it clearly fed into a personal view of True Religion.

Many of his book illustrations are quite literal depictions of the texts they accompanied. However, in the allegorical title pages, De Hooghe often presents a personal interpretation. Here he shows a consistent concern for True Faith, or the invisible True Church, that does not coincide with any of the formal confessions or religious groups of his time. The title print of Het Voorhof der Ziele, a volume of religious emblems by the Catholic poet Frans van Hoogstraten (I632-I696), ${ }^{26}$ is fairly typical. It shows the figure Pious Soul, approaching his heavenly destination. He wears a tunic printed all over with religious symbols. In his hand Pious Soul carries a burning heart, symbol of love, and he goes barefoot as a penitent. His head is crowned with laurels, and an angel guides him towards Christ who meets him with wide-open arms. In the background a steep stairway leads to Heaven. Behind the figure of Christ we see an allegory of the Pious Soul: a naked man, carrying a cross towards Heaven.

Cross-bearers occur often in prints by De Hooghe. They refer to the theme of the Imitation of Christ and seem to be derived from earlier Jesuit devotional works. Boëthius à Bolswert (c. 1580-1633) put them in the illustrations he made for Antoni Sucquet's Via vitae aeternae (I620), and we also see them on the engraved title page of Herbert Rosweyde's De Naervolginghe (163I). One of the illustrations in Via vitae aeternae even has hovering angels, or probably the winged souls of the saved, carrying crosses. We find a very similar image on a later title page by De Hooghe, where Christ himself is shown soaring among the clouds, carrying his cross. ${ }^{27}$

Among the authors whose work De Hooghe illustrated were prominent politicians like Constantijn Huygens and Nicolaes Witsen (I64I-I7I7). In the course of his career De Hooghe drifted more and more towards collaboration with authors with known enlightened views. Apparently he was in a position to be discriminating. He contributed to quite a few antiquarian and historical works critical of religion in general and of the official, State-protected Churches of the time in particular. The allegories he designed for these books are often much more complex. Examples are his illustrations for Verhandeling van de oude Orakelen der Heydenen by the Haarlem Mennonite physician Anthoni van Dale (I6381708 ${ }^{28}$ and Historie der Kerken en Ketteren, the Dutch translation of the well-known critical church history by Gottfried Arnold (I666-I7I4), Lutheran minister in Giessen, Germany. ${ }^{29}$

Van Dale gives a very erudite, but also very sceptical, description of the various forms of divination in classical antiquity. He systematically
De Hooghe, Van de loop van Hemel en Aarde, 1690-1708

etching, Hieroglyphica, plate I2

Three cosmological models: in the lower left corner, the Ptolemaic system, with Earth as an old but fertile woman (multiple breasts, flowered skirt) surrounded by a complicated array of circles. In the lower right corner, an equally contrived system found among the peoples of Siam. In the upper half, the Copernican view of the solar system, with the Sun $(G)$ in the centre; orbited by Mercury (H), Venus (I), Earth (K) and Moon (L), Mars (M), Jupiter (N) and Saturn (O). The text mentions Saturn's five moons. Note that the solar system is surrounded by infinite space, filled with other stars, each with their own planetary systems, reminiscent of the Cartesian theory of 'vortices'. 
compares the oracles of the ancient world with claims of exceptional spiritual gifts or demonic powers by his contemporaries. The latter had unfailingly been proven false, and even worse: as fraudulent ploys to part gullible fools and their money.30 De Hooghe's illustrations provide impressions of what the sanctuaries housing the oracles might have looked like. One print, however, resumes the argument of Van Dale's entire work. False Religion is here depicted as an idol in the form of a (golden) calf accompanied by two female figures. One is veiled and masked and stands on cat's feet: symbols of falseness and deceit. She holds the consciences captive, depicted as two prisoners in chains, carrying the attributes of inconstancy and blindness. The second female figure has five breasts - a reference to the ancient cult of Diana in her embodiment of fertility. Her head has three faces and is crowned by a mousetrap. She represents the temptation of superfluous knowledge.

Only one figure in this crowded print can escape the lures of False Religion: a donkey. This humble animal has its eyes fixed upon a crucifix, which is firmly rooted in a rock next to an open Bible and a skull, denoting the pious contemplation of mortality and salvation. Patiently, the donkey suffers the weight of a fat monk marked with the donkey's ears of stupidity - a devotee of False Religion and an icon of priestcraft. In the background we see a temple court surrounding a high mountain. It is inspired by the popular image of the Tabula Cebetis, a Renaissance allegory on the itinerary of the human soul with its ethical choices. Here sacrifices are being offered on altars decorated with crosses. Small human figures carry crosses along a steep road to the top of the mountain. Again, self-sacrifice and imitation of Christ are presented as the marks of True Religion. Emphatically, the clergy of the established Churches is shown as lacking knowledge of True Religion, in contrast to the simple souls, represented in the humble beast of burden. ${ }^{31}$

For the Dutch translation of Arnold's Unpartheyische Kirchen- und Ketzer-historie, De Hooghe made the title print. It shows Naked Truth: a nude woman, crowned with a wreath of laurels and carrying the standard of Christ in her right hand. Like her Lord, she rises from an open grave, triumphing over False Religion, which is embodied in four allegorical figures. Two of these symbolise priestly tyranny over the consciences of the faithful, carrying as attributes, among other things, the manybreasted Diana, a mask and cat's claws. One of them has fallen on his face. Two others represent the collusion of religion with political power: a Moor with a drawn sabre and a helmeted bishop carrying a world orb, bolts of lightning and a bunch of keys.

These emblems of oppression are contrasted with figures representing True Faith: one of them a simply dressed, venerable old man with his hands joined in prayer. Elsewhere in the work of De Hooghe we find a similar figure standing for the persecuted Church 'under the Cross', the very subject of Arnold's work. ${ }^{22}$ The old man rests his foot on the prone priest figure, sharing in the triumph of Naked Truth. The other represents the method for gaining truth. It is a sitting man, with his back to the viewer and his gaze fixed upon the central figure of Naked Truth. His tunic is covered with wide-open eyes. The wings of quick intellect adorn 
his head. In his lap he has an open book. In a balance he weighs a sword and a pillar: symbols of attack and defence in debate. Condescendingly, he wards off fame and fortune, represented in a trumpet, a cauldron full of coins and the coiled snake of envy. Like Arnold's text, the print calls for unfettered and unbiased inquiry into the mysteries of religion. Such an inquiry requires clear vision, sharp intellect and a careful weighing of arguments, without considerations for worldly gain.

Many elements from these title pages - with their emphasis on inner piety, free inquiry into religious truth and the rejection of ecclesiastical power - return in De Hooghe's posthumous Hieroglyphica. Here, however, we also find the reflection of an interest in the natural sciences and in the 'cultural anthropology' inspired by the voyages of exploration and the enormously popular travel literature. As with True Religion and the enlightened critique of religion, we can trace De Hooghe's interest in these fields through the books to which he contributed his artwork. The impressive list of these books contains microscopical studies of Antoni van Leeuwenhoek (1632-1723); medical books by De Hooghe's good friend Govert Bidloo (I649-I7I3); Francesco Redi’s (I626-I697) work on insects; and descriptions of travels to China, the Indies and Muscovy. In the same way, books on antiquity, law and history for which he produced plates and title pages probably informed De Hooghe's Spiegel van Staat. ${ }^{33}$

\section{An artistic critique on religion}

It is not an easy task to give a good impression of Hieroglyphica, and plainly impossible to do justice to its complexity in only a few pages. Although book-sized, the work does not offer a continuous text. For each of the plates, De Hooghe wrote an extensive legend, providing an audience less erudite than he was himself with the information necessary to grasp the significance of its various elements. Like the plates themselves, the text is often open to various readings. It is left to the reader to construe the overall argument of the book from these disjointed and, probably deliberately, ambiguous explanations. The 63 etched plates are crowded with allegorical figures and abound in symbolism and learned references. ${ }^{34}$ Despite De Hooghe's declaration of intent in the introduction, it is not quite an iconology in the sense of Cesare Ripa's Iconologia (1593) or Johannes Pierius's Hieroglyphica (I566). ${ }^{35}$ De Hooghe refers to the difficulties artists often encountered when they had to depict the ancient gods correctly and gallantly offers to share his deep erudition in this field with fellow artists lacking in formal education, but the plates in his Hieroglyphica are absolutely unsuited as models to be copied for drawing.

Many emblem books claim usefulness as a treasure trove for later artists, and De Hooghe's introduction follows this convention of the genre. ${ }^{36}$ In doing so, however, De Hooghe also self-consciously presented himself as a master of his art. At the time the Hieroglyphica was made, De Hooghe was the director of a drawing academy in Haarlem..$^{37}$ As such, he was, in a way, the successor of Carel van Mander (I548-1606), who had a similar school there a century earlier. In fact the Hieroglyphica may have been inspired by Van Mander's Schilderboeck. The Schilderboeck was 


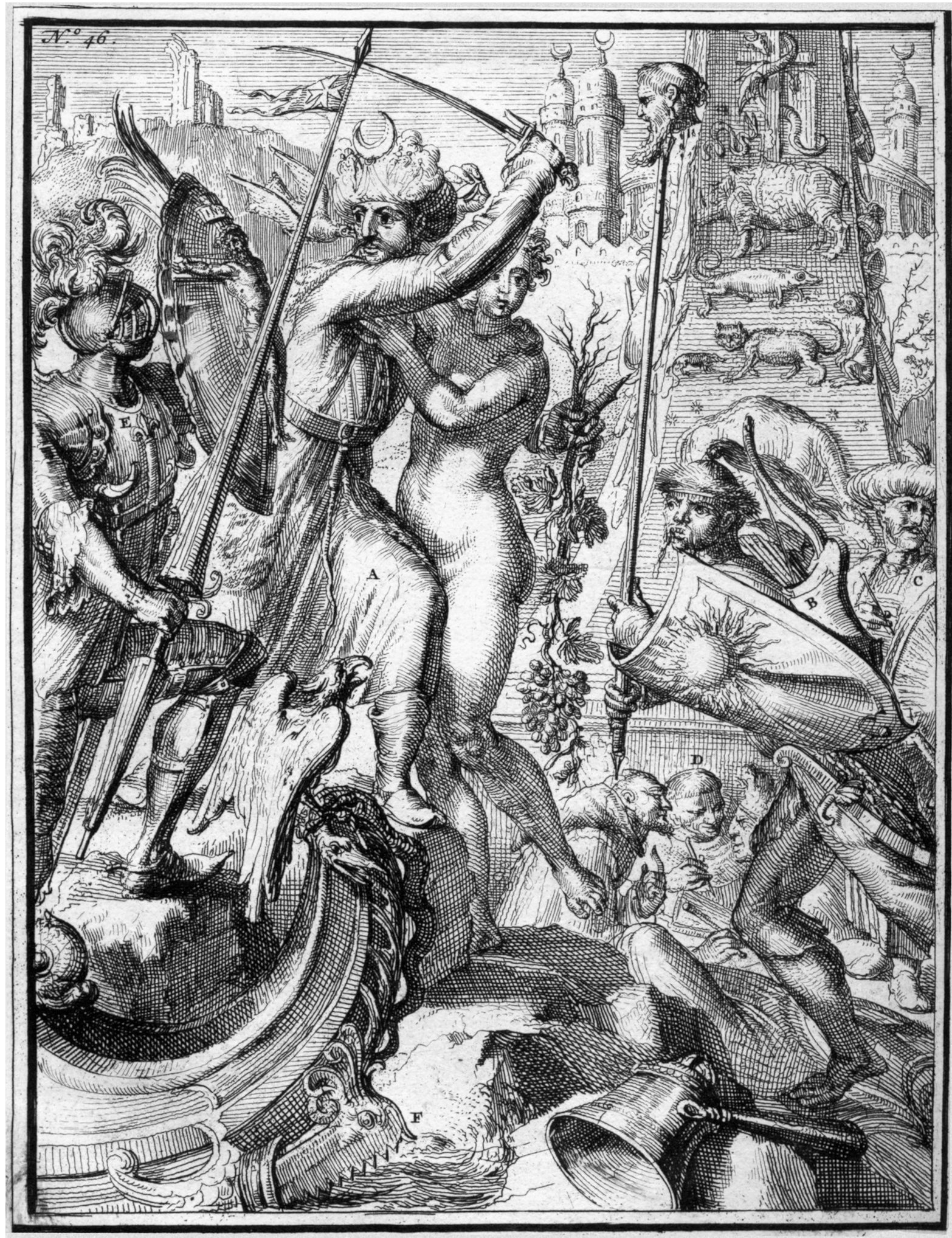


published in 1604, and besides a compendium of famous painters, it contains a eulogy to the art of painting and its ability to edify and entertain at the same time..$^{38}$ The first chapter of the Hieroglyphica eloquently discusses the similar, or even superior, powers of the emblem.

The Hieroglyphica may even have been intended as a homage to the work of Van Mander and to the Haarlem magistrates who had offered De Hooghe citizenship when he moved to their city in I679 after his conflicts with the regents of Amsterdam. On one of its plates he included a ship with a sawtoothed keel, the invention claimed by Haarlemmers as the key to success in the capture of Damietta during the Fifth Crusade, and the central icon of Haarlem's civic pride (fig. 2). ${ }^{39}$ In the accompanying text the glorious deeds of the medieval Haarlemmers are explicitly compared to the valour of the Dutch navy that used their technique in capturing the English flagship at Chatham (I668) and a Spanish silver transport in the bay of Vigos (I702).40 The penultimate chapter contains a veiled reference to the controversial work Den Hemel op Aarden (1703) by Frederik Leenhof (I647-I7I2), a Reformed minister of Zwolle and admirer of Spinoza (fig. 3).4ז De Hooghe must have completed the Hieroglyphica between 1703 and 1708, the year he died, a full century after Van Mander's

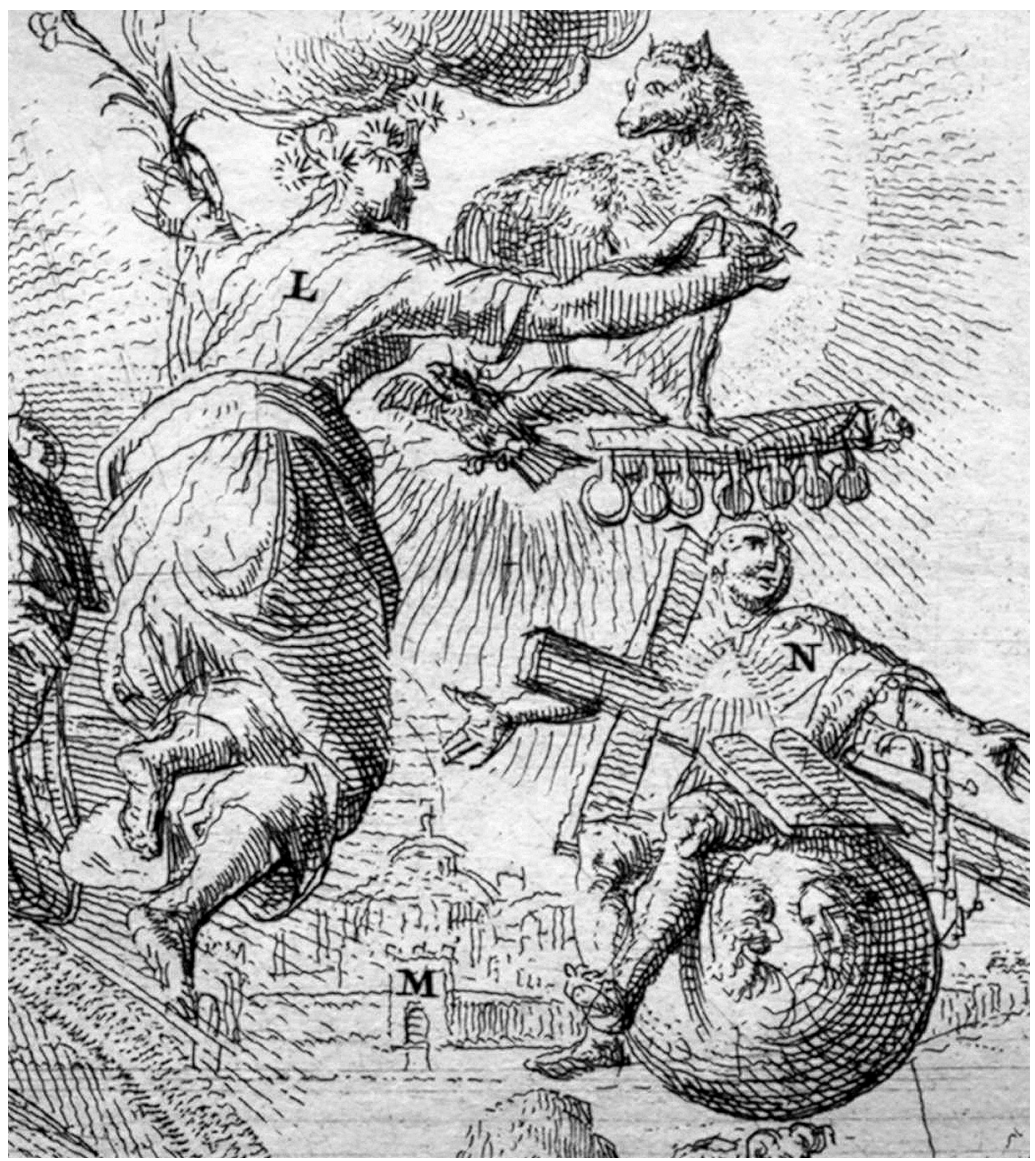

De Hooghe, Van de Mabometaansche beginselen, 1690-1708

etching, Hieroglyphica, plate 46.

This allegory on Islamic culture contains the image of a Crusader (left margin) disembarking from a ship with a sawtoothed keel, the emblem of the city of Haarlem. Contemporary views on Islam often emphasised its violent character; De Hooghe shows here that violence is anything but an exclusively Islamitic vice.

De Hooghe, Van verscheyde gewaande en den waaren Hemel, 1690-1708 (detail: centre, top third)

etching, Hieroglyphica, plate 62

This print as a whole is filled with the fictitious imaginings of the afterlife. By contrast, this group shows the real Heaven. The True Church (L), devoid of political aspirations, ascends towards God, interested only in the spiritual, Heavenly Jerusalem (M). The Truly Faithful (N) has his Heaven on Earth: knowing that Christ has redeemed him on the Cross, in life he blissfully rejoices in God's mercy. He is shown as a laughing man, who takes whatever life brings him as God's gift and does not fear death. 


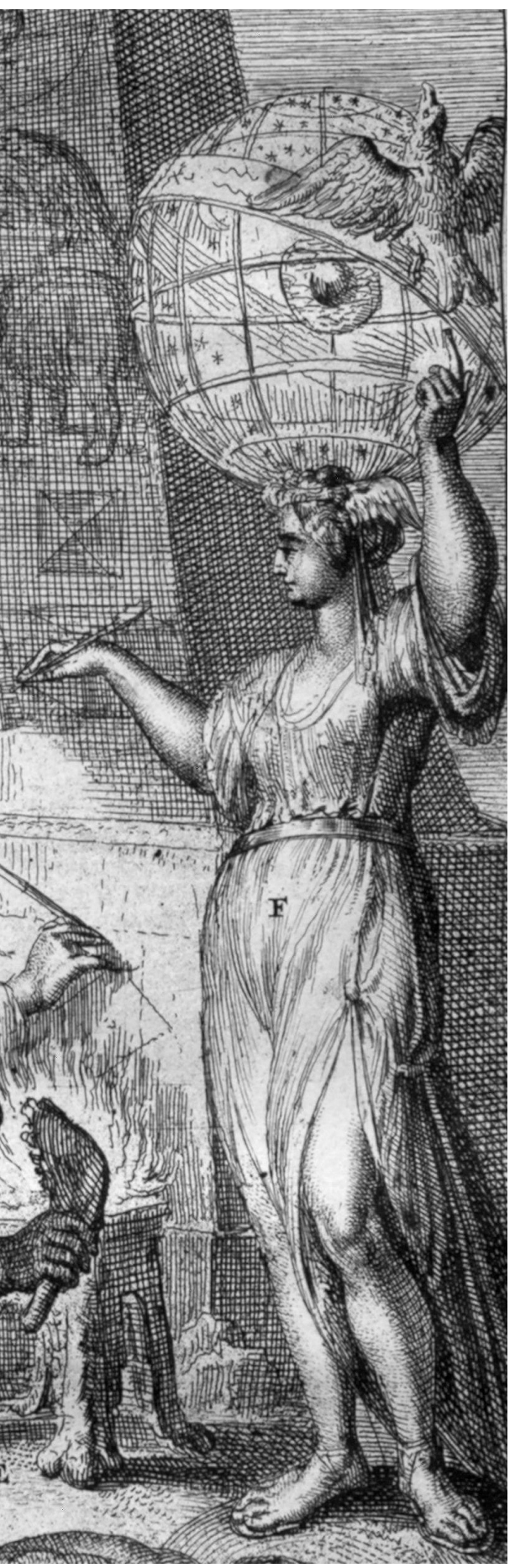

Schilderboeck. By including the Damietta ship, De Hooghe shows he was prepared to contribute to the civic patriotism of his new city of residence. ${ }^{42}$

The main thrust of the Hieroglyphica, however, is a critique of the religion of De Hooghe's day. He introduces his subject in the title of the book as 'the progressive decline and corruption of religion through the ages, and its recent reformation continuing until the present day'. At first sight the book provides a chronicle of the history of religions. We see the many gods and demons of the pantheon shared by the civilisations of antiquity, each with their attributes, followed by plates illustrating the rise of Christianity and its relations to the religions of the world. On closer inspection, however, the book is anything but antiquarian. Rather than a history, the Hieroglyphica offers a genealogy of religion. ${ }^{43}$

De Hooghe argues that religion originated in the science of astronomy as it was first developed in the ancient Middle East. The astronomers of those days reached high levels of sophistication, which enabled them to determine the best times for sowing, planting and harvesting. They were the first natural scientists. The common people, however, ascribed their knowledge, gained from careful observation and computation, to a presumed access to divine mysteries. In this way, the astronomers, unwilling to disabuse the people of their misconceptions, acquired enormous prestige and a priestly status. Princes deftly exploited the reverence of the common people for the scientist-priests. Between them, princes and scientists produced a cult of the gods, personifications of the forces of nature and deified rulers and heroes. By the grace of these invented gods they won from the common people obedience to their rule and their taxation regimes (fig. 4).

The thesis that all religions are descended from the mythography of the ancients, based on antique astronomy and natural philosophy, runs as a continuous argument through the entire book. Everywhere, the power of princes and the wealth of noble and priestly elites have been based on the local form of religion, however varied the world's religions may seem on the surface. De Hooghe exploits the knowledge - accumulated in the antiquarian scholarship, merchant ventures and voyages of exploration of the Golden Age and made accessible in an extensive travel literature - to present a kaleidoscopic picture of ancient and contemporary religious beliefs and customs. He states that the nature of the various peoples and the degree of religiosity found among them are dependent on the climate zones. Moreover, religions are not static entities, but develop over time, as the cultures in which they are embedded develop. But underneath this dazzling variety in outward appearance, and their variability over time, all religions essentially share this same root in 'applied science'. Christianity is no exception to this rule: it is simply the religion best suited to the nature of Europeans.

The first half of the Hieroglyphica presents ancient conceptions about gods, the cosmos, the world, mankind and the human soul. These plates often show the starry heavens, armillary spheres, the signs of the zodiac, and other symbols for the heavenly bodies. From time to time De Hooghe complements his presentation of ancient myths with more recent 
faits divers on exotic peoples and their religious customs. Throughout his work, he compares these mythical and historical data with the biblical narrative. He gradually steers his readers from the pagan world of antiquity to contemporary views on world history, as constructed by humanist scholars on the basis of biblical histories and the chronologies extracted from the Bible. Implicitly, the Bible and Christianity are presented as the products of human projection, as, by their nature, all religions are. De Hooghe boldly states that the most clear-sighted individuals have always been aware of this: the mysteries of religion are 'a great nothing'. But by exposing this 'bowl of Roses' - a euphemism for a used chamber-pot with its malodourous contents - one risked bloody persecution by priests and princes. ${ }^{44}$

The projection theory underpinning the entire argument of the book is further shored up by repeated references to the discussions on philosophy and discoveries in the natural sciences. De Hooghe proves himself well aware of these contemporary discussions and how they transformed the traditional discourse on the history of salvation and undermined belief in the factual truth of Scripture. When presenting the teachings of various religions on the structure of the cosmos, he uninhibitedly ridicules belief in comets and other phenomena as the harbingers of disaster. ${ }^{45} \mathrm{He}$ scorns the rejection by theologians of the Copernican system. He presents the old Ptolemaic system as a heathen invention, as much as the model of the cosmos from Siam that he had seen in the collection of the father of Jan Swammerdam (I637-I680) (fig. I).$^{46}$ In this context he repeatedly refers to the hypotheses about sentient life on the moon and other celestial bodies as so much poetic licence, meant to taunt overzealous bigotry. ${ }^{47}$

In ironical asides about the reliability of biblical history he draws attention to the inconsistencies and outright contradictions in the biblical narrative. These had been discussed in learned treatises by generations of biblical scholars, but had only recently been presented to a more general audience by radical philosophers like Thomas Hobbes (I588-1679) and Spinoza - and by a rebellious theologian like Balthasar Bekker. ${ }^{8}$ In his treatment of prophecy De Hooghe sneers at the 'theologia emblematica' popular among theologians of his days: the art of finding allegorical references to profound religious wisdom in 'ordinary' words and names in the Bible - for instance, in the rather tawdry and technical descriptions of the building of Solomon's Temple. ${ }^{49}$ And he shares the sarcasm of Bekker about the popular beliefs in demons and devils in a covert reference to the latter's controversial book De betoverde weereld..$^{\circ}$

The chapters on the ancient gods soon become rather repetitive. De Hooghe seems to have spun his classical mythology out to such an extent with an eye towards the overall composition of the book. In the division of subject matter over the 63 chapters, De Hooghe mirrors the history and morally questionable achievements of religion in pagan antiquity, in chapters up to and including 3I, against the gradual corruption of religion in the Christian era from chapter 33 to the end. Chapter 32, exactly in the middle of the Hieroglyphica, represents the Incarnation of Christ. This dogma is not represented in a traditional nativity scene, however. For De
4

De Hooghe, Rakende de naam en eerste gang van de Hieroglyphica of Beeldspraak-Konst in het gemeen $1690-1708$ (detail: right margin) etching, Hieroglyphica plate 2

Lady Philosophy, her head winged to denote quickness of mind. She researches the heavens (on her head) and the Earth (on which she stands). She records her findings with a sponge-capped stylus, always prepared to amend unsatisfactory formulations. She points to the eagle that flies vertically upwards, the symbol of speculative theology. Fully informed about the natural causes of comets and other frightening phenomena, she none the less interprets them for the common people as signs of divine wrath, to keep them in obedience. This may be deceit, but it is politically expedient. 
5

De Hooghe, Van Christus in 't vlees, I690-1708

etching, Hieroglyphica, plate 32

De Hooghe's True Church, depicted in three stages: in the lower left corner, the simple soul following Christ (A). She stands with one foot in the river Jordan (baptism), and she accepts from Christ's hand the cup of the Last Supper. Above her, the Church that accepts the Cross, overcomes the strictures of the ceremonial Law, and against which Death and the Gates of Hell do not prevail (C). Finally, the Church entering the gate of heaven, surrounded by references to the biblical prophecies (E).

The cornucopia she carries denotes their fulfillment.

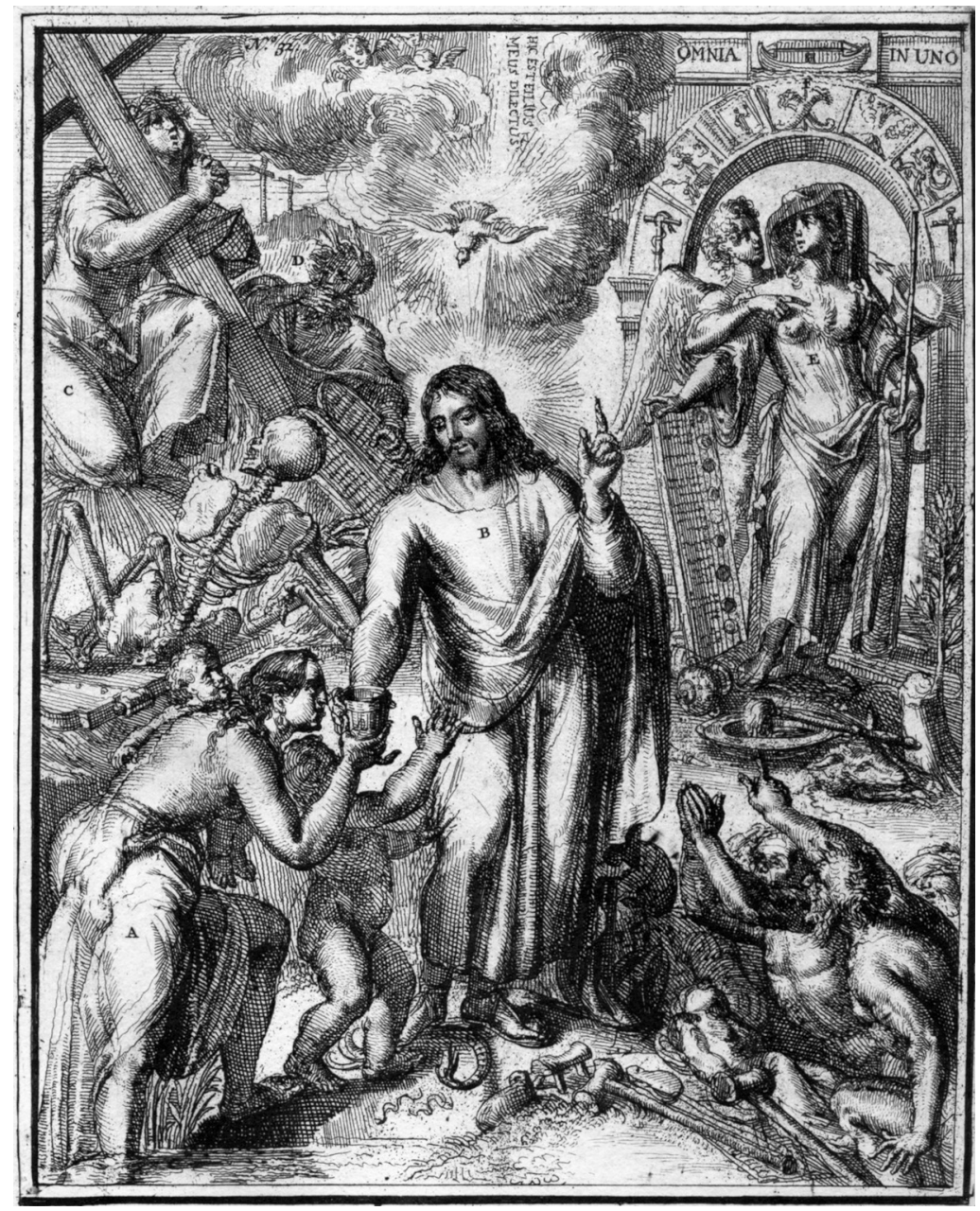

Hooghe the embodiment of Christ is the Christian Church, represented here in a triad of female figures: as a humble, half-naked mother surrounded by small children, stretching out her arms to Christ; as a woman worshipfully clasping the Cross; and as the accomplished Christian soul, enlightened by the Spirit to see through the outward forms and ceremonies. In this triad De Hooghe constructs an ideal Christianity: a church of true believers, followers of Christ, for whom power, religious authority and theological learning are irrelevant (fig. 5). ${ }^{\mathrm{sI}}$ As the Incarnation is the heart of the Christian Scriptures, so this 32nd chapter is the heart of the Hieroglyphica, strategically placed in the centre of its composition - at the price of repetitiousness in the chapters on the classical pantheon.

The factual history of Christianity, however, presents us - according to De Hooghe - with the opposite of this spiritualist ideal. The Early Church was rent by theological conflict, scorning simple piety. The central message of the Gospel that the law had been fulfilled with the coming of Christ could not prevent the imposition of new laws and 
religious obligations by precisians who pretended to know better than the truth revealed in the Bible. ${ }^{52}$ This imperiousness of self-proclaimed ecclesiastical authorities harmed the Church more than the persecutions of pagan princes and led to persecution among Christians. The Peace of God's Church can be attained only when the Church is content with the central tenets of the Christian faith and leaves individual Christians completely free in their study and interpretations of the sacred mysteries.53

Prelates and theologians are rarely presented in a favourable light in the Hieroglyphica. By accepting their authority and obeying their commands, the common faithful fall prey to slavish dependence, existential doubt, anguish of conscience or theological pedantry. ${ }^{54} \mathrm{De}$ Hooghe displays a boundless confidence in the natural religiosity of the common people. This is graphically represented in the figure of Balaam's Ass. ${ }^{5}$ This animal plays a curious role in the biblical story of the Old Testament prophet Balaam. Seduced by a large sum of money, the prophet had consented to curse the Israelites so that the King of Moab could defeat them in battle. When God sent an angel to intercept Balaam on his way to the battlefield and prevent this evil plan, it was the humble ass that saw the angel and stopped in its tracks, whereas the prophet himself was blind to the heavenly messenger (fig. 6). ${ }^{66}$ De Hooghe uses Balaam's Ass as the emblematic representation of the simple faithful who have, as if by instinct, a deeper insight into the nature of religion than kings and prophets, prelates and theologians. In this sense Balaam's Ass figures in two rather central places in the Hieroglyphica, in the chapters on the decline of the Church and on the dawn of reformation..$^{57}$ Innate religiosity is not typical for Christian lay believers only: in a plate on the nature of Islam, the more exotic dromedary takes the place of the ass in representing the piety of the Muslim faithful - sober, modest, trustworthy and industrious - again as opposed to the cruelty and deceitfulness of their political and religious leaders. ${ }^{8}$

The divisions of Christianity into rival Churches strengthened the

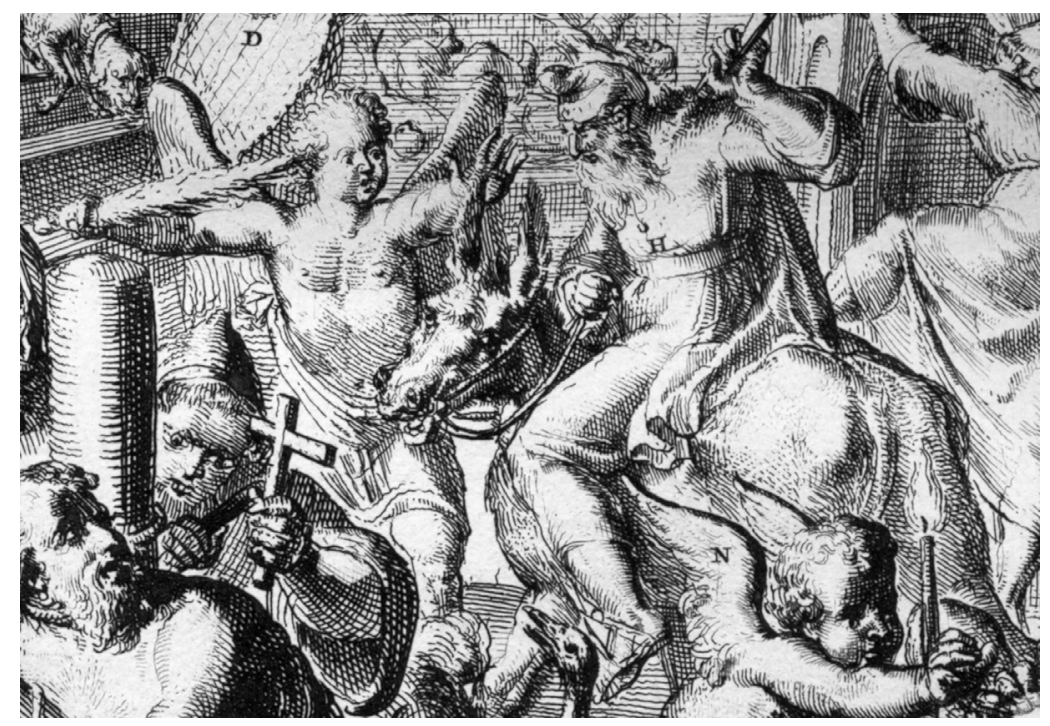

6

De Hooghe, Van de aankomende Hervorming, 1690-1708 (detail: centre) etching, Hieroglyphica, plate 56

Balaam's Ass refuses to heed the blows of its unseeing rider as it sees the Angel blocking its path. This image is applied in the text to the simple people of the high valleys of Savoy, Bohemia, the Alps and Pyrenees (Waldenses, Hussites, Albigensians), persecuted for their faith, but eventually redeemed as torchbearers of reformation. 


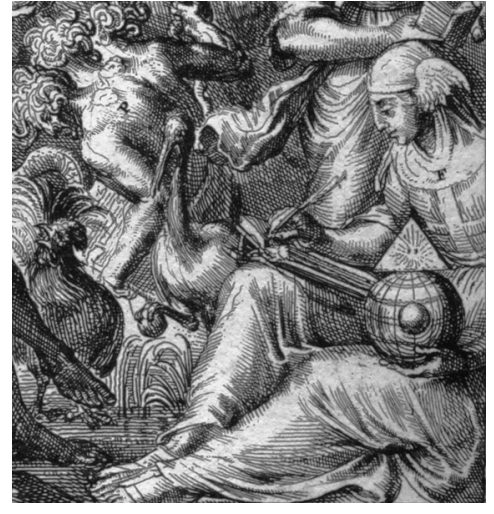

7

\section{De Hooghe, Van den Oorsprong en} Voortgang der Ordens in de Roomsche Kerk, I690-1708 (detail: lower right corner)

etching, Hieroglyphica, plate 4I

Praise for the intellectual labour of the medieval monks, who studied both nature (world orb) and its Creator (triangle with the All-Seeing Eye), teaching and edifying the faithful with their writings.

8

De Hooghe, Van de Gereformeerde Godsdienst, 1690-1708

etching, Hieroglyphica, plate 6I

De Hooghe shows Reformed Religion as a form of True Religion. To the left of the central figure are two sisters, representing the schools of Voetius and Cocceius. During De Hooghe's lifetime these two schools had been embroiled in bitter controversies. Here they stand for the devout life and speculative theology respectively, as two complementary sides of Reformed Religion. Note the two figures in the lower left corner: the Synod of Dordrecht $(\mathrm{F})$ protected by the States of Holland. power of secular and religious authorities. Persecution of heretics - from Albigensians (presented as precursors of the Huguenots) to Muslims served to increase their power and wealth. The Crusades produced the Military Orders as the storm troopers of the Catholic Church. Although De Hooghe rejects monastic rules as a straightjacket that inhibits natural religiosity and leads to hypocrisy and other vices, he praises the monastic virtues of voluntary poverty, obedience, scrutinizing of the conscience, chastity, discipline and industry (fig. 7).59 These he considers not as specifically monastic, but rather as common Christian - or even human virtues. The only Catholic saint to receive a separate treatment in the Hieroglyphica is St. Christopher, characterised by De Hooghe as a mirror of Christian virtue. The legendary St. Christopher was converted from a life of vice and purified his soul by carrying the Christ Child, heavy with the sins of fallen humanity, over the water. For De Hooghe this makes him an example of true piety, and the opposite of the corrupted Balaam. ${ }^{60}$

The pretentions of the medieval Church, supported by the power of princes and the authority of Councils and canon law, were undermined by 'The Dawn of Reformation'. ${ }^{6}$ For De Hooghe this phrase does not indicate a specific historical period, but rather a conglomerate of medieval heretical groups. By the end of the seventeenth century these had been coopted into the genealogy of Protestantism because of their rejection of ecclesiastical institutions, rituals or specific points of doctrine (fig. 6). De Hooghe here follows the views of Gottfried Arnold, with which he was well acquainted, as he designed and etched the illustrations for the Dutch translation of his Unpartheyische Kirchen- und Ketzer-historie. ${ }^{62}$ For De Hooghe, reform of the Church had not been completed with the establishment of Protestantism. He highly praises the efforts of Martin Luther (I483-I546) and Frederick III, Elector of Saxony (I463-I525), for their contributions to reformation, but the Churches that originated in their wake created opportunities for new forms of religious fraud, power play and the contentiousness of theological schools. De Hooghe devotes a plate and chapter specifically to forms of 'misguided reformation', which disrupt Christian commonwealths through hypocrisy, blasphemy, schism and wars of religion. ${ }^{63}$ The Protestant Churches were therefore in need of continual reformation. He presents his ideal for Dutch Reformed Protestantism as a (provisional) end station of this process. According to this ideal, the Church should teach simple imitation of Christ, allowing for a variety of devotional styles, under the tutelage of political power.

Remarkable in this respect is De Hooghe's treatment of the Synod of Dordrecht and the States of Holland: together they represent for him the highest authority in the Dutch Reformed Church (fig. 8). The opinion that the Church was subject to the sovereign power of the State and was bound to maintain the doctrines and church ordinances established by political authority was not uncommon in the Dutch Republic, ${ }^{64}$ but against the background of the larger argument unfolded in the Hieroglyphica we may confidently see this as a reference to the political philosophies of Hobbes and Spinoza. When the authority of the Church is thus firmly bridled by the State, it can focus upon its true mission: the cultivation of piety. De Hooghe represents true piety in the guise of two 


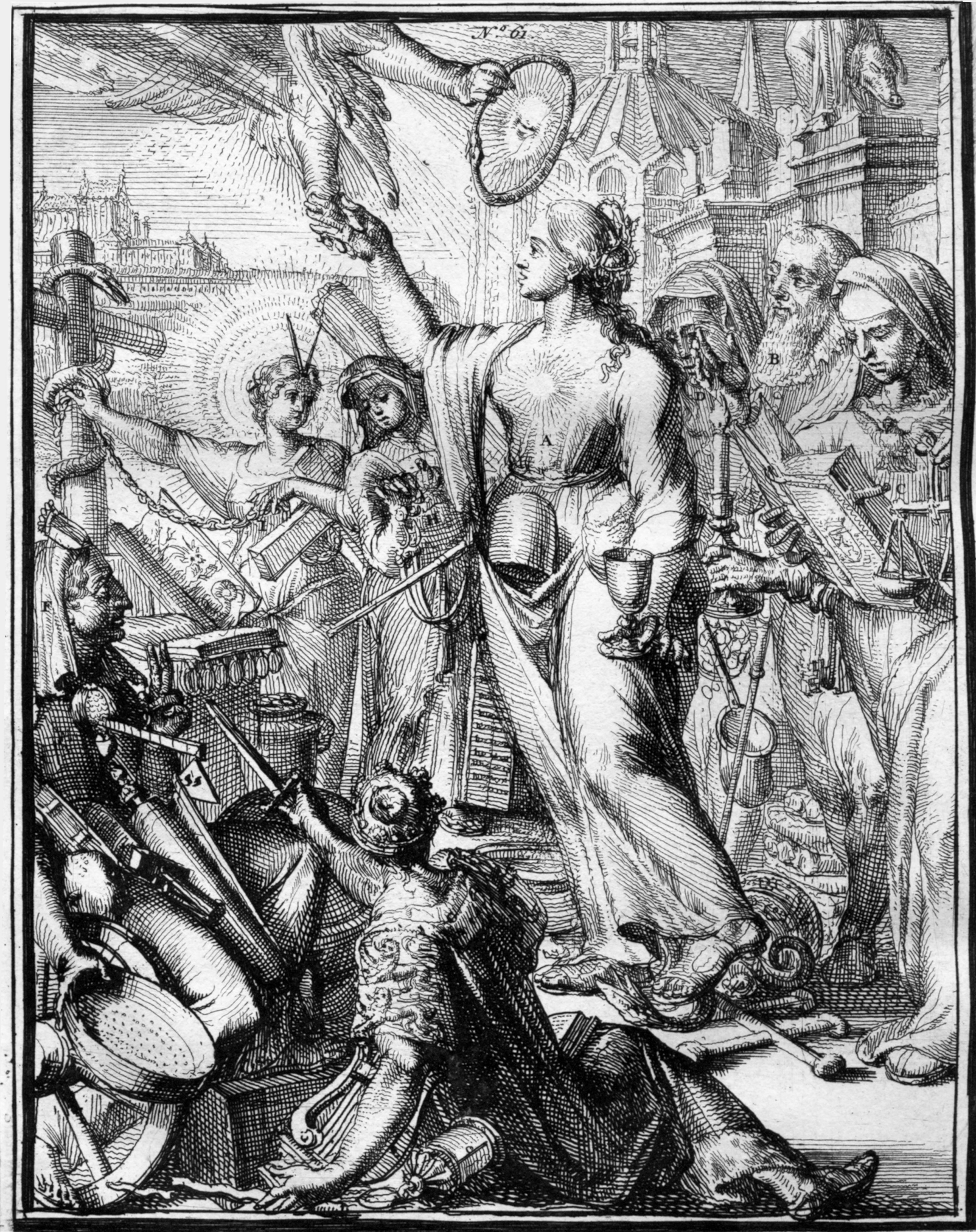




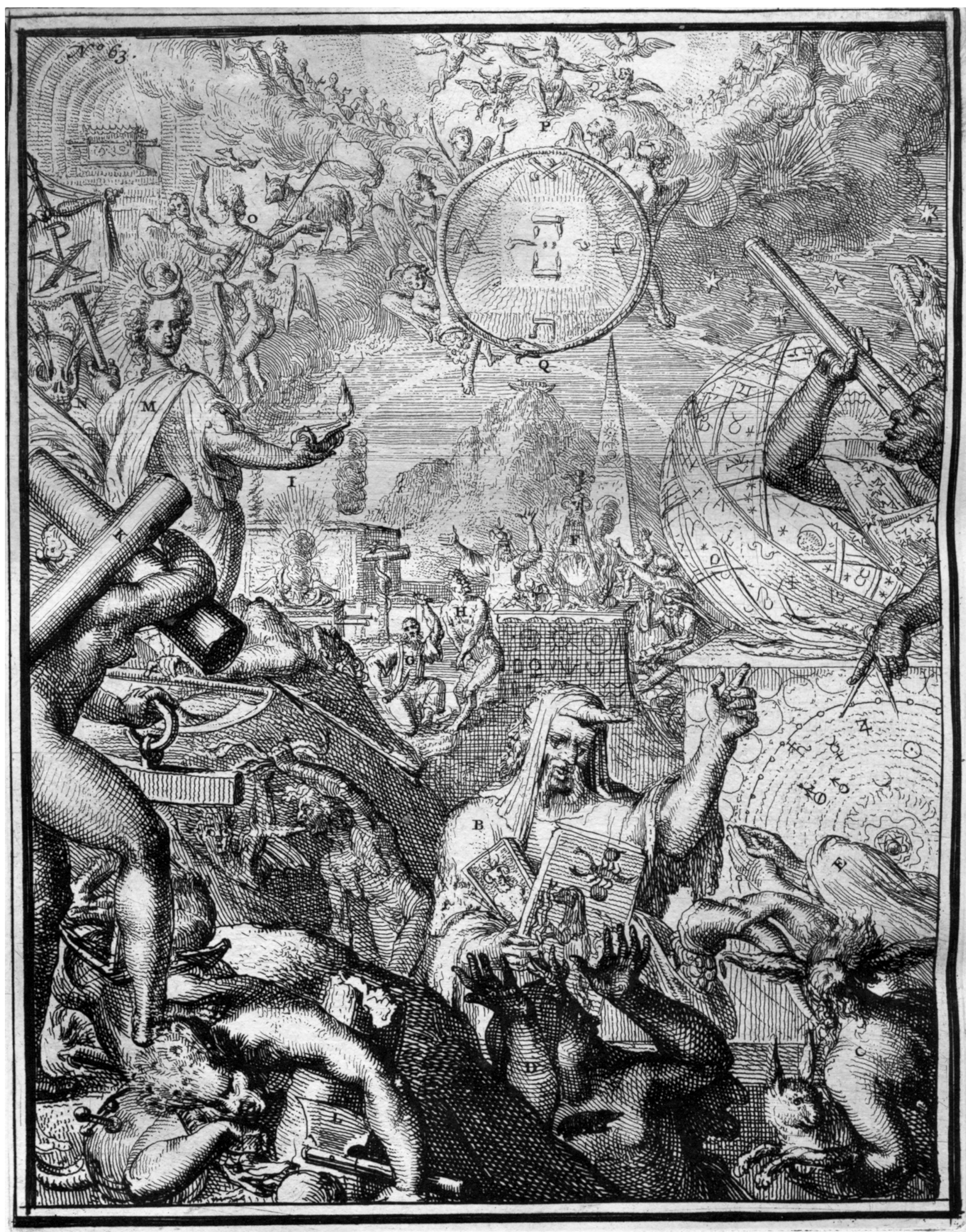


sisters, practical and theoretical theology, the embodiments of the schools of Voetius and Johannes Cocceius (I603-I669). As sisters they are equal, and they should compete - not for hegemony over the Church or for the upper hand in a casuistry that perverts the preaching of the Gospel, but for excellence in piety only. The central message of the 32nd chapter on the Christian Church as the Incarnation of Christ on earth is recapitulated here and applied to the recent theological conflicts in the Dutch Reformed Church.65

In the final chapter De Hooghe summarises the entire genealogy of religion. Again he starts with its origin in ancient astronomy, visualised in the anachronistic image of a Chaldean magus with an enormous telescope. The magus leans upon a model of the system of the world, identified as the mysterious 'machine' built by the Alkmaar mathematician Cornelis Drebbel (I572-I633) and presented to James II of England (I633-I7OI) - a model of the world that, according to De Hooghe, was so accurate that it even predicted the weather. ${ }^{66}$ From there he restates his general argument: that the one and only legitimate aim of religion is to enable people to find the way to attain the salvation of their souls. The hallmark of every civilised society is that it is religious and offers its members the freedom to perfect their souls and prepare them for ascending to God. The Chaldean magus, a scholarly researcher and seeker of truth before his kind succumbed to the lures of priestcraft, has his telescope trained on Christ in Heaven (fig. 9).67 The penultimate chapter 62 demonstrates that the salvation De Hooghe has in mind is not the afterlife of conventional Christian theology. In this chapter De Hooghe gives a comparative description of ancient and exotic conceptions of the destination of the human soul after death, arguing that they are all equally the product of projection. The True Church is the imagined community of all those who bear their cross in the imitation of Christ and who joyously strive towards Heaven. And the God ruling this Kingdom is 'the Beginning without beginning and the End without end'. This use of the traditional alpha-and-omega metaphor for God reflects in the case of De Hooghe the Spinozist worldview of God as all-encompassing and unending Nature. ${ }^{68}$

The central argument of De Hooghe's Hieroglyphica was entirely too radical to be published during De Hooghe's lifetime. The plates must have been puzzling even to a contemporary intellectual audience, but the vernacular textual legend left little room for doubt about their maker's intentions. Unlike the republican political philosophy of Spiegel van Staat, the enlightened critique of religion of the Hieroglyphica remained unpublished for decades. The context of its eventual publication and its readership are as yet unexplored. ${ }^{69}$ However, it may not be a coincidence that the work finally appeared in 1735 , just a few years before the completion of the multivolume Cérémonies et coutumes religieuses de tous les peuples du monde by Bernard Picart (1673-I733) and Jean Frederic Bernard (I683-I744). Both works put the universal claims of Christian Churches in perspective and advocated tolerance..$^{70}$ Of the two books, De Hooghe's Hieroglyphica is the more outspoken and offers a more fundamental critique of formal religion. It reflects the various intellectual strands that went into the radical phase of the early Enlightenment and, more specifically, the impact of the cosmological debates on theology.
De Hooghe, Toepassing, 1690-1708

etching, Hieroglyphica, plate 63

Recapitulation of the over-all argument of the book. Note the Chaldean, symbol for the 'invention' of religion, with his telescope trained on Christ in Glory. The orb behind him represents the mysterious 'machine' devised by Drebbel. 


\section{Science and religion}

With hindsight, the suspicions of De Hooghe's orthodoxy were certainly correct. In the Hieroglyphica he shows his true colours. Playing upon the declared principles of Protestantism - rejection of ecclesiastical hierarchy and scholastic theology and a reading of the Bible unfettered by tradition - he argues for a highly unorthodox religion of humanity. The recent reformation, to which the title of the book refers, is not the emergence of Protestantism but rather of enlightened Christianity, based on freedom of inquiry and freedom of conscience. Individuals imitate Christ according to their own lights, within the constraints of outward conformity to the established Churches and obedience to political authority - as did De Hooghe himself. ${ }^{\text {I }}$

Like his artistic style, De Hooghe's views on True Religion seem to have formed early in his life. They inform all his artwork for books on religion. His earliest commissions betray familiarity, if not affinity, with Counter-Reformation Catholic devotional styles. It has been argued that early modern Catholicism, with its 'cult of introspection', was more 'modern' than the various forms of Protestantism. ${ }^{72}$ De Hooghe valued this type of spirituality, localised in the individual conscience. Faith based on doctrine alone had nefarious side-effects ranging from cruel persecution to superstitious fear. Freedom of personal choice did not, however, invalidate the State's demands for outward conformity, which was simply a necessary form of social discipline. The Church should be subject to State regulation as well, to preclude priestcraft. Religion was to be used for religious purposes only: to make people pious and virtuous. What is implicit in the title pages of the works De Hooghe illustrated becomes explicit in the text of the Hieroglyphica.

De Hooghe was an exponent of the radical Enlightenment of the second half of the seventeenth century. Enlightenment thought, grounded in new epistemology and the recent discoveries in natural philosophy, questioned early modern religious establishments, theology and political theory. The lively debates in this field - not least in cosmology but also in theology and the beginnings of comparative religion - left their traces in the Hieroglyphica. De Hooghe's allegories show how even Reformed Protestantism was deformed by the elementary forms of priestcraft inherited from its long genealogy in the ancient Middle East, and which it had in common with the world's religions. Emphatically, De Hooghe advocates a freedom of inquiry that takes seriously even the most far-reaching consequences of the scientific and scholarly revolutions of his time, also when these run counter to the Biblical worldview. True Faith can be based only on a free moral judgement of the believer. The history of religions teaches that gods and demons are the product of human projection and that the gods worshipped by man are either deified men or the powers of nature. In his radical deconstruction of Christianity, De Hooghe reveals himself a fullblooded Spinozist. ${ }^{73}$ Like Spinoza, he was not an atheist in the modern sense. His work is infused by an enlightened spirituality. Measured by the religious codes of his own time, he was every inch the libertine his 


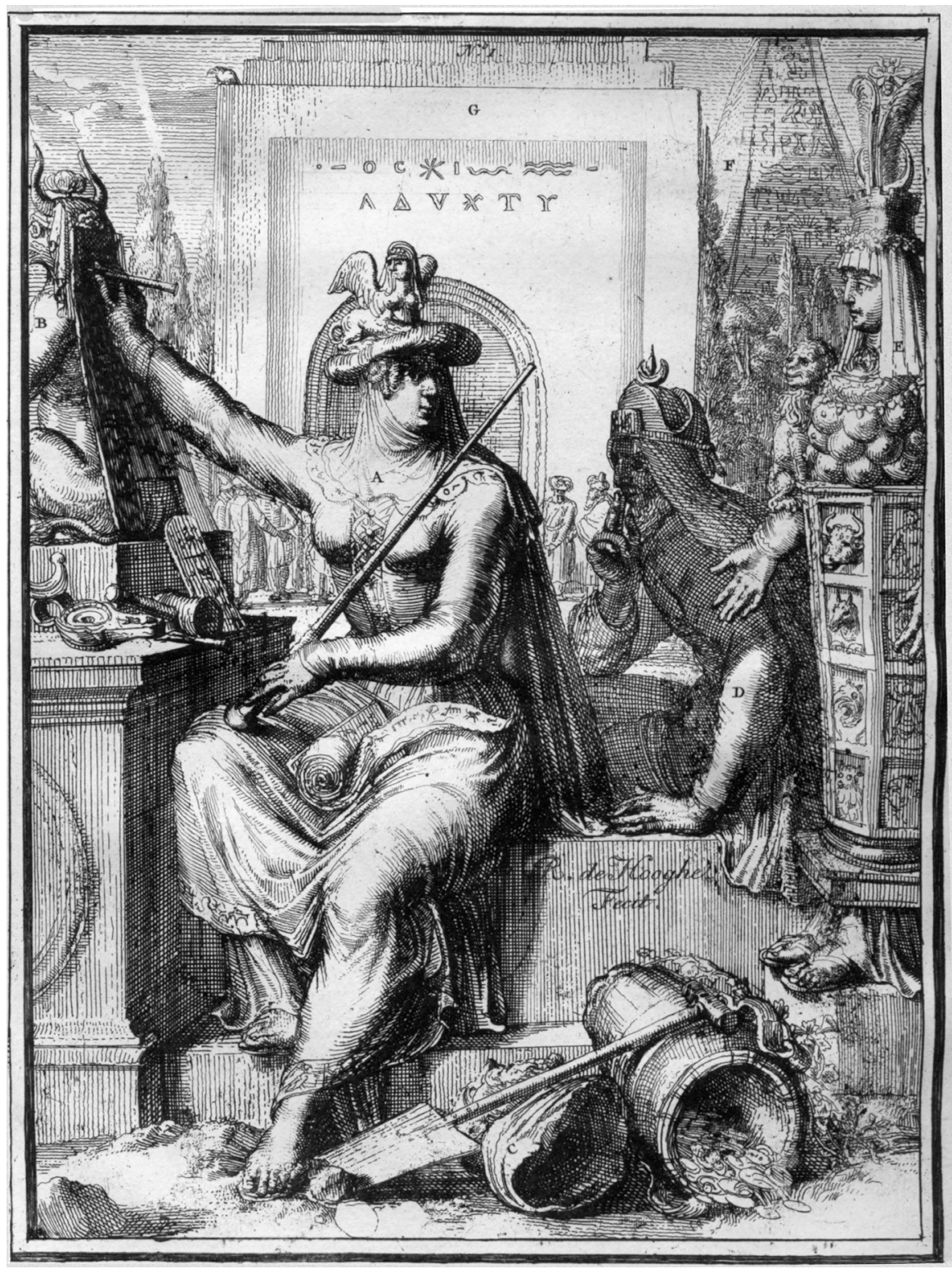

enemies claimed he was, but in a much more interesting way than any pornographer could ever be. ${ }^{74}$

It is not without reason that the Hieroglyphica was published only in I735, long after the author died. Characteristically, the first plate shows the allegorical figure of the inventress of emblems - she who perceives the true nature of things and knows how to depict them allegorically accompanied by the figure of a priest of Harpocrates: the Egyptian god of secrecy, the one who knows how to interpret emblems but keeps his knowledge to himself, depicted with his finger on his closed mouth (fig. Io). Both are, of course, representations of De Hooghe himself.
IO

De Hooghe, Uytlegging van de Prent- en Merkbeelden der Egyptenaren. Wat dezelve zyn; haar oorsprong en voortgang, I690-1708

etching, Hieroglyphica, plate I

The central figure is the maker of hieroglyphs; the dark figure behind her represents a priest of Harpocrates. 


\section{Notes}

I De Hooghe I706, cf. Israel 2006, via the entry 'De Hooghe' in the index.

2 Hieroglyphica, or emblems of the ancient peoples (...) containing an exhaustive essay on the progressive decline and corruption of religion through the ages, and its recent reformation continuing until the present day.

3 Iversen I993. See also the article by Thijs Weststeijn in this volume.

4 De Hooghe I735, 24-25.

5 Klever I992; Oudaen I690; cf. Anonymous I690; De Hooghe I690.

6 On the shady reputation of promotions at Harderwijk, see Frijhoff 2000, 26-29.

7 De Hooghe I735, I26.

8 Elias I903-I905, vol I, 453.

9 Andriesse I993, II9-I47.

Io Vermij 2002.

II Huygens I689; Seidengart I981; Dekker I986.

12 For 'moon-stories' as a satirical genre, see Christianson 1976; Cressy 2006.

I3 Bekker I69I-I693, vol I, I34-I35. On the status of mathematics, cf. Van Bunge 200I, 60-6I.

I4 Fix I999; Spaans 2007.

I5 On this bafflement, also in the world of the microscopically small, see Ruestow 1996.

I6 Form, background and intention of Cosmotheoros are currently the subject of a master's thesis by Joas van der Schoot at Utrecht University.

I7 Van Bunge 200I; Cools et al. 2006; Van Bunge I996; Vermij 2002.

I8 Champion I992; BarnettI999.

I9 Weekhout 1998.

20 Cf. Israel, 200I, 275-327.

2I Vermij 2002, I88-237.

22 Van Rooden 2000.

23 Van der Haar I956; De Haas 2008; Leemans 2008. Leemans misjudges De Hooghe's familiarity with theological debate, and mistakes conformity for orthodoxy.

24 Frijhoff \& Spies I999, 359.

25 Leeflang 2008, I27, I3I.
26 Van Hoogstraten i668. On Van Hoogstraten, see Zuidema I930.

27 Sucquet I620, plates 2I (p. 45I) and 20 (p. 569); Rosweyde I63I. See airborne cross-bearers in Sucquet, pl. 29 and the title page to the New Testament in De Hooghe I703. For another Catholic devotional project, see Coppens I995.

28 Van Dale I687, I42.

29 Arnold I7OI-I729.

30 Cf. Palingh I659; Bekker I69I-I693.

3I Van Dale 1687 , next to p. 8I.

32 De Hooghe I735, plate 39, figure F.

33 Verkruijsse 2008.

34 Although he rejected the idea of a universal language, De Hooghe obviously shared the interest of his contemporaries in pictography; see the article by Thijs Weststeijn in this volume.

35 De Hooghe cites both authors by name in his address to the reader.

36 Van der Coeleni999, 264-265.

37 De Haas 2008.

38 Porteman \& Smits-Veldt 2008, I66-I67

39 Spaans I989, I28-I30; Frijhoff 2006.

40 De Hooghe I735, 340-34I, and plate 46.

4I Ibid., 447-448; Wielema 2004, IO3-I32.

42 Cf. De Haas 2008, I7.

43 Wilson I974, 3I4-32I, loosely characterises the book as 'an Encyclopedia of World Religions', which entirely misses the point.

44 De Hooghe I735, 403.

45 Ibid., 27-28.

46 Ibid., I22-I23, I26, and plate I2. See also the contribution by Eric Jorink earlier in this volume.

47 De Hooghe I735, I23, I39.

48 Ibid., I65. For the history of a critical study of the Bible in the Republic, see Van Bunge 200I, I6I-I62, and Jorink 20IO, 88-IO5.

49 De Hooghe I735, I86-I88. On emblematic theology, see Van Asselt 1997, and on the interest in the building of Salomon's Temple, Van Asselt 1996.

so De Hooghe I735, 237.

5 I Ibid., 255-257.
52 Ibid., 26I

53 Ibid., 269-270.

54 All four thematised in De Hooghe I735, plate 39, the figures A, B, C and $\mathrm{M}$.

55 De Hooghe I735, 29I, 405.

56 Numbers 22-24.

57 De Hooghe I735, 29I, 405.

58 Ibid., 338. Plate 46 has the dromedary on the monument in the upper right corner, half hidden by the 'Asian' warrior. See also the contribution by Dániel Margócsy in the present volume.

59 De Hooghe I735, 303-309, 35I-355.

6 Ibid., 387-388.

6I The title of chapter 56 in De Hooghe I735, cf. 405-407.

62 Arnold I7OI-I729.

63 Plate and chapter 6o, De Hooghe 1735 , 427-433.

64 Schilling I993.

65 De Hooghe I735, 435-44I (plate 6I).

66 Ibid., 449; cf. Vermij 2002, 92-97.

67 De Hooghe I735, 454, cf. II9, I85.

68 Ibid., 443-448 (plate 62).

69 Hieroglyphica is the subject of the $\mathrm{PhD}$ project of Trudelien van 't Hof at Utrecht University.

70 Hunt et al. 20I0. It is not unlikely that the Hieroglyphica, even if as yet unpublished, influenced the work of Picart and Bernard, but no research has been done in this direction as yet.

7I Van Rooden 2000.

72 Nalle 2004, 323.

73 Cf. Van Rooden I984. Israel 2006, 245 characterises De Hooghe as a disciple of Spinoza for his republicanism. Israel ignores Hieroglyphica or De Hooghe's views on religion.

74 Although no outright pornographic work is known from his hand, he did have a taste for the genre. In chapter 27 of his Hieroglyphica he writes that he refrains from elaborating on more salacious aspects of Venus, as these often cause offence, but that, given time, he will do so in forthcoming work; De Hooghe I735, 229.

\section{Bibliography}

Andriesse I993

C.D. Andriesse, Titan kan niet slapen. Een biografie van Christiaan

Huygens, Amsterdam \& Antwerp 1993.

Anonymous 1690

Anonymous, Het eerste Antwoort tegen Romeyn de Hooge (...) [I690]

(Knuttel I3548A).
Arnold I70I-I729

G. Arnold, Historie der Kerken en Ketteren van den beginnen des

Nieuwen Testaments tot aan het Jaar onses Heeren I688, Amsterdam \&

Groningen I70I-I729.

Barnett 1999

S.J. Barnett, Idol temples and crafty priests. The origins of Enlightenment anticlericalism, London \& New York 1999. 
Bekker I69I-I693

B. Bekker, De betoverde weereld, zynde een grondig ondersoek van 't gemeen gevoelen aangaande de Geesten, deselver Aart en Vermogen, Bewind en Bedryf; als ook 't gene de Menschen door derselver kraght en gemeenschap doen, Amsterdam I69I-I693.

Champion 1992

J.A.I. Champion, The pillars of priestcraft shaken. The Church of England and its enemies, I660-I730, Cambridge 1992.

Christianson 1976

G.E. Christianson, 'Kepler's Somnium. Science fiction and the Renaissance scientist', Science Fiction Studies 3 (1976), 79-9I.

Cools et al. 2006

H. Cools, M. Keblusek \& B. Noldus (eds.), Your humble servant. Agents in early modern Europe, Hilversum 2006.

Coppens 1995

C. Coppens, Een Ars Moriendi met etsen van Romeyn de Hooghe. Verhaal van een boekillustratie, Brussels 1995.

Cressy 2006

D. Cressy, 'Early modern space travel and the English man in the moon', American Historical Review III (2006), 961-982.

De Haas 2008

A. de Haas, 'Commissaris van zijne majesteit en mikpunt van faamrovende paskwillen. Een biografische schets', in: Van Nierop et al. 2008, I2-3I.

De Hooghe 1690

[R. de Hooghe], Nieuw oproer op Parnassus. Zijnde een verhaal van de valse Getuygen (...) teegen den Heer en Meester Romein de Hooge (...), [I690] (Knuttel I3547).

De Hooghe 1703

R. de Hooghe, Alle de Voornaamste historien des Ouden en Nieuwen Testaments, verbeeld in uytsteekende Konst-Platen. Met omstandige verklaring der stoffen, en seer beknopte Punt-Digten, van den Eerw. Godsgel. Heer Henricus Vos. Waar by ook gevoegt zyn Nieuwe Kaarten, tot opheldring der zaaken nodig, Amsterdam 1703.

De Hooghe 1706

R. de Hooghe, Spiegel van Staat des Vereenigde Nederlands, Amsterdam I706.

De Hooghe 1735

R. de Hooghe, Hieroglyphica of merkbeelden der oude volkeren, namentlyk Egyptenaren, Chaldeeuwen, Feniciers, Joden, Grieken, Romeynen, enz. Nevens een omstandig Bericht van het Verval en voortkruypende Verbastering der Godsdiensten door verscheyde eeuwen; en eyndelyk de Hervorming, tot op deze tyden toe vervolgt. Overzien en Beschaaft door Arn. Henr. Westerhovius, Amsterdam I735.

Dekker 1986

E. Dekker, 'Sterrekunde in de zeventiende eeuw', De zeventiende eeuw 2 (I986), 84-I00.
Elias 1903-1905

J.E. Elias, De Vroedschap van Amsterdam 1578-1795, Haarlem I9031905 .

Fix 1999

A. Fix, Fallen angels. Balthasar Bekker, spirit belief, and confessionalism in the seventeenth-century Dutch Republic, Dordrecht 1999.

Frijhoff 2000

W.T.M. Frijhoff, 'De betekenis van de Harderwijkse universiteit in internationaal perspectief, in: Het Gelders Athene. Bijdragen tot de geschiedenis van de Gelderse universiteit in Harderwijk (I648-I8II), Hilversum 2000, 15-36.

Frijhoff 2006

W.T.M. Frijhoff, 'Damiette appropriée. La mémoire de croisade, instrument de concorde civique (Haarlem, $\mathrm{XVI}^{\mathrm{e}}-\mathrm{XVIII}{ }^{\mathrm{e}}$ siècle)', Revue du Nord 88 (2006), no. 364, 7-42.

Frijhoff \& Spies 1999

W.T.M. Frijhoff \& M. Spies, I650. Bevochten eendracht, Den Haag 1999 .

Hunt et al. 2010

L. Hunt, M.C. Jacob \& W. Mijnhardt, The book that changed Europe. Picart and Bernard's 'Religious ceremonies of the world', Cambridge, MA \& London 2010.

Huygens 1689

C. Huygens, Cosmotheoros. De wereldbeschouwer, (P. Rabus, transl. (1754); H.A.M. Snelders, ed.), Utrecht 1989.

Israel 200I

J.I. Israel, Radical Enlightenment. Philosophy and the making of modernity, I650-I750, Oxford 200I.

Israel 2006

J.I. Israel, Enlightenment contested. Philosophy, modernity, and the emancipation of man 1670-1752, Oxford 2006.

Iversen 1993

E. Iversen, The myth of Egypt and its hieroglyphs in European tradition, Princeton 1993.

Jorink 2010

E. Jorink, Reading the book of nature in the Dutch Golden Age, I575I7IS, Leiden \& Boston 2010.

Klever 1992

W. Klever, 'Inleiding', in: F., Vrije politijke stellingen, Amsterdam I992, I3-II9.

Leeflang 2008

H. Leeflang, 'Waarheid, vlugheid en inventie. Ontwerp en uitvoering van de etsen', in: Van Nierop et al. 2008, I26-I45.

Leemans 2008

I. Leemans, 'De viceroy van de hel. Radicaal libertinisme', in: Van Nierop et al. 2008, 32-47. 
Nalle 2004

S.T. Nalle, 'Self-correction and social change in the Spanish CounterReformation', in: J.D. Tracy \& M. Ragnow (eds.), Religion and the early modern state. Views from China, Russia, and the West, Cambridge 2004, 302-323.

Oudaen 1690

J. Oudaen Fransz., Op de regtsvordering van de Heer Mr. Adriaan

Bakker, Hooft-Officier der Stad Haarlem, tegen de persoon van Romeijn de Hooge, Wijlen Plaetsnijder tot Amsterdam. Tot voorstand des Gerechts, en vordering der Eere Gods, [I690] (Knuttel I3544).

Palingh 1659

A. Palingh, 't Afgerukt mom-aansight der tooverye, daar in het bedrogh der gewaande toverye naakt ontdekt en met gezonde redenen en exempelen dezer eeuwe aangewezen wort, Amsterdam I659.

Porteman \& Smits-Veldt 2008

K. Porteman \& M.B. Smits-Veldt, Een nieuw vaderland voor de

Muzen. Geschiedenis van de Nederlandse literatuur I560-I700,

Amsterdam 2008.

Rosweyde I63I

H. Rosweidius, De Naervolginghe Christi van Thomas a Kempis (...). Mitsgaders sijn leven, Antwerp I63I.

Ruestow 1996

E.G. Ruestow, The microscope in the Dutch Republic. The shaping of discovery, Cambridge 1996.

Schilling 1993

H. Schilling, 'Afkeer van domineesheerschappij. Ein neuzeitlicher Typus des Antiklerikalismus', in: P.A. Dykema \& H.A. Oberman (eds.), Anticlericalism in late medieval and early modern Europe, Leiden I993, 655-668.

\section{Seidengart I98I}

J. Seidengart, 'Les théories cosmologiques de Christian Huygens', in: Huygens et la France. Table ronde du Centre national de la recherche scientifique, Paris 198I, 209-222.

Spaans 1989

J. Spaans, Haarlem na de Reformatie. Stedelijke cultuur en kerkelijk leven I577-I620, The Hague 1989.

Spaans 2007

J. Spaans, 'Censorship, satire and religion. A seventeenth-century satirical print on the condemnation of Balthasar Bekker's "The Enchanted World”', in: J.A.C. van Ophem \& C.H.E. Verhaar (eds.), On the mysteries of research. Essays in various fields of Humaniora,

Leeuwarden 2007, 273-287.

Sucquet 1620

A. Sucquet, Via vitae aeternae, Antwerp 1620.

Van Asselt 1996

W.J. van Asselt, 'Ultimum tempus nobis imminet. Eschatologische structuren van de theologie van Johannes Coccejus's, Nederlands Archief voor Kerkgeschiedenis / Dutch Review of Church History 76 (1996), I89-226.
Van Asselt 1997

W.J. van Asselt, 'De neus van de bruid. De profetische en zinnebeeldige godgeleerdheid van Henricus Groenewegen en Johannes D’Outrein', in: F.M.G. Broeyer \& E.M.V.M. Honeé (eds.), Profetie en godsspraak in de geschiedenis van het christendom. Studies over de historische ontwikkeling van een opvallend verschijnsel, Zoetermeer 1997, I63-184.

Van Bunge 1996

W. van Bunge, 'Eric Walten (I663-1697). An early Enlightenment radical in the Dutch Republic', in: W. van Bunge \& W. Klever (eds.), Disguised and overt Spinozism around I700, Leiden I996, 4I-54.

Van Bunge 200I

W. van Bunge, From Stevin to Spinoza. An essay on philosophy in the seventeenth-century Republic, Leiden $200 \mathrm{I}$.

Van Dale I683, I687

A. van Dale, De oraculis ethnicorum dissertationes duae, Amsterdam I683 (=Verhandeling van de oude Orakelen der Heydenen, Amsterdam I687).

Van der Coelen 1999

P. van der Coelen, 'Emblemata sacra? Biblical picture books and emblem literature', in: J. Manning, K. Porteman \& M. Van Vaeck (eds.), The emblem tradition and the Low Countries, Turnhout 1999 , 26I-278.

Van der Haar 1956

C. van der Haar, 'Romeyn de Hooghe en de pamflettenstrijd van de jaren 1689 en 1690, Tijdschrift voor Geschiedenis 69 (1956), I55-17I.

Van Hoogstraten 1668

F. van Hoogstraten, Het Voorhof der Ziele. Behangen met leerzaeme Prenten en Zinnebeelden, Rotterdam I668.

Van Nierop et al. 2008

H.F.K. van Nierop et al. (eds.) Romeyn de Hooghe. De verbeelding van de late Gouden Eeuw, Zwolle \& Amsterdam 2008

Van Rooden 1984

P.T. van Rooden, 'Spinoza's bijbeluitleg', Studia Rosenthaliana I8 (1984), I2O-I33.

Van Rooden 2000

P.T. van Rooden, 'Vroomheid, macht, verlichting', De Achttiende Eeuw 32 (2000), 57-75.

Verkruijsse 2008

P. Verkruijsse, 'Door Romeijn de Hooghe geschreven en geïllustreerde boeken', in: Van Nierop et al. 2008, 258-290.

Vermij 2002

R. Vermij, The Calvinist Copernicans. The reception of the new astronomy in the Dutch Republic, I575-I750, Amsterdam 2002.

Weekhout 1998

I. Weekhout, Boekencensuur in de Noordelijke Nederlanden. Een verkennend onderzoek naar de vrijheid van drukpers in de zeventiende eenw, The Hague 1998. 
Wielema 2004

M. Wielema, The march of the libertines. Spinozists and the Dutch Reformed Church (I660-1750), Hilversum 2004.

Wilson 1974

W.H. Wilson, The art of Romeyn de Hooghe. An atlas of European late Baroque culture, Cambridge, Mass. 1974 (unpub. diss. Cambridge,

MA).

Zuidema 1930

R. Zuidema, 'Hoogstraten, Frans of Francois van', in: P.C.

Molhuysen \& P.J. Blok (eds.), Nieuw Nederlands biografisch

woordenboek, Leiden I9II-I937, vol. 8, 833-834. 